\title{
Examining the Economic and Political Dimensions of the Eastern Mediterranean Problem from a Macroeconomic Perspective within the Framework of Neo-Realism and Neo-Liberalism
}

\author{
Hasan Alpago ${ }^{1}$ \\ Mine Kılınç ${ }^{2}$
}

\begin{abstract}
The United Nations Convention on the Law of the Sea uses the concept of a country's designation as an Exclusive Economic Zone for coastal countries that extend beyond its territorial waters. Accordingly, a state within a 200mile zone has the right to extract natural resources. On the other hand, since the Turkish Republic of Northern Cyprus is not recognized by other states, according to international law, the entire island is still subject to the Republic of Cyprus. In other words, the Greek Cypriot part of the island is accepted as the Republic of Cyprus and in this respect, this region is seen as the Exclusive Economic Zone of the Republic of Cyprus. However, Turkey argues that the islands are not an Exclusive Economic Zone and therefore sees gas exploration as legitimate. Instead, Turkey considers the coastline of the mainland mass in the Eastern Mediterranean to be very important. On this basis, the Turkish government claims a part of the marine area as the Exclusive Economic Zone, and therefore the natural gas deposits here are located on the Turkish continental shelf. Turkey also demands that the internationally unrecognized Turkish Republic of Northern Cyprus receive a share of the revenues from its gas reserves. This study aims to evaluate this complex problem from a macroeconomic perspective within the framework of neo-realism and neo-liberal perspectives.
\end{abstract}

Keywords: Eastern Mediterranean, Turkey, Greece, Cyprus, France, Neorealism, Neoliberalism, Balance of Power

\footnotetext{
${ }^{1}$ Dr., Nisantasi University, Aviation Management, Orcid: 0000-0001-7695-2794, halpago@yahoo.com. ${ }^{2}$ Istanbul University, Medical Faculty, Specialist, Orcid: 0000-0002-6462-8126, mine.kilinc@windowslive.com.

* Research Article. Received: 29.09.2021, Accepted: 18.10.2021.

DOI: 10.17932/IAU.FCPE.2015.010/fcpe_v07i2003
} 


\section{INTRODUCTION}

According to neo-liberal economic and political views, the primary concern of countries in international relations is to protect their own economic and political interests. However, method and policy changes occur from time to time due to the conjuncture. For example, the economic and political policies followed during the Cold War period and the policies followed in the globalizing world in line with the technological innovation and digitalization that came to the fore in every field, especially in the fields of production and consumption, differ in many respects. However, there is one thing that is common in every period and that is the economic and political interests of the countries that change over time. For this reason, social scientists in fields such as politics and economics, which have developed different theories, try to explain these changing relations within the framework of these theories. On the other hand, neo-liberal and neorealist approaches come to the fore more economically and politically throughout the world. This fact is valid for the Eastern Mediterranean problem. Normally, this problem arises from the disagreements between Greece and Turkey. However, especially the attitude of Greece causes other actors such as France to get involved in this problem. In this respect, this study aims to address the evaluation of the Eastern Mediterranean problem with a systematic scientific approach.

When the essence of the subject is examined, the source and results of the problem can be evaluated in an understandable framework. In July 2020, Turkey announced that it sent a drilling ship to the region for the search for oil and natural gas energy resources near the island of Crete and that these studies will continue by increasing it has brought some problems with it. Turkey justified this by referring to the memorandum of understanding signed with the UN-recognised Libyan government in November 2019 on the delimitation of maritime zones in the Eastern Mediterranean. However, other Mediterranean countries such as Greece and France rejected the agreement, arguing that the agreement ignored Crete's presence between the Turkish and Libyan coasts. Later, especially France started to follow active policies against these plans of Turkey and acted as the main actor in an anti-Turkey policy.

According to neo-liberalism, states are not self-sufficient units and are not the only actors in world politics. In addition to classical intergovernmental 
relations, transnational relations play an important role. That is, in addition to states, there are other influential actors such as multinational companies, banks, or scientific expert groups. States and their existence are accompanied by political power plays and power processes. Their interrelationship is an area of analysis in the interdependence approach. Since both the Eastern Mediterranean problem and other existing problems require international solutions, the necessity of international alliances comes to the fore.

On the other hand, in the world economy dominated by neo-liberal understanding, an understanding prevails that reserves such as oil and natural gas are the key to economic power, and that those who own them can own the world and then rule over it. Today, this approach is seen in this way both in terms of neo-liberalism and neo-realism. In this respect, the Eastern Mediterranean problem and the policies followed can be based on this approach. Because it has both an economic purpose due to underground energy resources such as oil and natural gas, and a political goal in terms of penetrating the region and directing the international power balance according to its own interests. For this reason, it would be more appropriate to try to explain it with neo-liberal and neo-realist theoretical approaches.

The ownership of the Eastern Mediterranean natural gas energy resources and the claims on these resources have both economic and political dimensions. More importantly, the debates on this subject have the feature of being a research topic in many respects in academic circles. Thus, it is important both in terms of international maritime law, the ownership of resources in international territorial waters and the international dimension of conflicts between countries. In this study, this situation has been tried to be evaluated by emphasizing that economic interests and political calculations have a neo-realist and neo-liberal character.

\section{BACKGROUND OF THE RESEARCH}

The natural gas dispute in the Eastern Mediterranean comes to the fore as a conflict over fossil fuels, especially natural gas, off the Cyprus coast. Disputes between the European Union, especially Southern Cyprus and Greece and Turkey regarding the underground resources in this lake have emerged since the 2000s. The gas dispute is part of the border dispute between Greece and Turkey, as well as the Cyprus conflict. Ultimately, 
the problems in the Eastern Mediterranean are mainly due to conflicts of interest and sovereign rights debates between Greece and Turkey.

Thus, both the economic and political interests of the parties conflict here. In this respect, the issue can be handled in different dimensions within the framework of neo-realist and neo-liberal policies. Namely, France and Greece see Turkey as a threat to their own economic and political interests. From this point of view, the sharing of energy reserves such as natural gas, which is estimated to be found in this region, and efforts to establish dominance in the region lie in the background of the international tension regarding the Eastern Mediterranean.

Table 1: Natural Resources in the Mediterranean Basin

\begin{tabular}{ll}
\hline & Quantity (cubic meters) \\
Oil reserve & 270 million $\mathrm{m}^{3}$ (1.7 billion barrels) \\
Natural gas Reserve & 3.45 trillion $\mathrm{m}^{3}$ \\
\hline
\end{tabular}

As a matter of fact, according to a study conducted by the US Geological Survey (USGS) in 2010, there are 3.45 trillion $\mathrm{m}^{3}$ natural gas and 270 million $\mathrm{m}^{3}$ (1.7 billion barrels) oil reserves in the Mediterranean basin. Natural gas on the Mediterranean floor can meet the energy needs of countries with direct borders such as Syria, Israel, Lebanon and Cyprus for many years. The largest known of these natural gas fields until 2013 is 510 billion $\mathrm{m}^{3}$ in Israel. In addition, it is estimated that there are 200 billion $\mathrm{m}^{3}$ reserves for the Aphrodite natural gas field in Cyprus (Yayc1, 2012:10-14). Due to the importance of these resources for the countries of the region, it is observed that new pipeline projects and equivalent alliances are formed (Ediger, Devlen, Mcdonald, 2012:83).

\section{METHODOLOGICAL APPROACH}

In this study, the subjects are discussed with a comparative analysis with a descriptive approach. One of the components of a research is to obtain sufficient information about the research problem. For this reason, the descriptive research method stands out as an important approach. In addition, since the approaches of Turkey and France will be discussed, the subject has been evaluated within the framework of neo-realism and neoliberalism approaches with a comparative analysis. 


\section{The research questions of the study are:}

-What is the role of energy resources in international relations?

-Why do natural gas reserves, which are estimated to be in the Eastern Mediterranean Region, cause problems between Turkey and Greece?

-Why is France intervening in the Eastern Mediterranean problem?

\section{THEORETICAL AND CONCEPTUAL FRAMEWORK}

In this study, the problems and tensions that emerged after Turkey's attempts to discover natural gas reserves in the Eastern Mediterranean were discussed within the framework of international neo-realism and neoliberalism theory. In other words, the causes and consequences of conflicts and search for solutions in the Eastern Mediterranean have been tried to be analyzed based on the theories of neo-realism and neo-liberalism. Neorealism or neo-realism theory is an extension of traditional power theories related to international relations and was first mentioned by Waltz in 1979 (Ünay, 1998: 208-210). Neo-liberalism, on the other hand, is a theory used to express economic liberalism and free market capitalism. Both neorealism and neo-liberalism are evaluated in this study because they bring the economic or political interests of countries to the fore in international problems (İlhan, 2019: 362).

In conclusion, the Eastern Mediterranean problem is an event with a multifaceted and complex history. Therefore, it is important to consider it from the perspective of both economic, political and international conflicts of interest.

Since the Eastern Mediterranean problem is a current and international problem, it is the subject of many scientific articles and books, especially by Turkey. In this respect, there is no shortage of resources in the literature research. It is possible to talk about a common feature of the sources discussed in this study. In almost all of them, the Turkey side theses are defended and the issue is handled as Turkey's just cause. In this respect, this study is mostly based on these sources and the subject is limited in terms of both theoretical, methodological and content. In terms of content, the subject has been dealt with within the framework of domination wars 
over energy resources. The theories used as methods and references are approaches such as neo-liberalism, neo-realism and partially dependency. However, it should be emphasized that it will not be sufficient to evaluate international problems only within the framework of a theory. It will only be able to shed light on one aspect of the problem. Because, especially in the globalizing world experiencing digital and technological revolutions, the relations between countries are experiencing a similar dynamic process.

\section{THE PLACE OF NEO-REALISM THEORY IN INTERNATIONAL RELATIONS AND THE EASTERN MEDITERRANEAN PROBLEM}

Since the 17th century, the balance of power in international politics in Europe has been the political order of sovereign states, which are in constant conflict with each other, but the weaker ones are always against them. The strongest do not wage unlimited wars against each other. In addition to the balance of power, the exercise of power by a hegemony and control of power through international agreements and institutions exist as a model for securing peace. In international relations theory, the distribution of power among states is a central theme of neorealistic interpretations (Yirmibeşoğlu, 2018:120).

The founder of neo-realism, Waltz systematically presents international relations as "interacting units" composed of structures and individual states. The balance of power states that states are actors in a structure where anarchy prevails due to the lack of central power. This anarchic situation forces states to act based on security and power (help yourself principle). After all, the highest national goal is the survival of states. States are rational actors driven by interests with different powers. State security policy is expected to guarantee its own strength, and this is in theory elevated to states' most urgent task. In this context, not only the military power of a state, but also its economic power plays an important role. According to Waltz, if there is a power imbalance, states tend to balance this power imbalance. He tries to do this with his own weapon or by forming alliances. Neo-realism theory developed by Waltz states that the international system consists of two important components. These are the structure, which is the characteristics of the international system, and the units within this system, namely the states. According to the neorealism approach, the following three basic principles shape the national and international policies of a state (Düzgün, 2020: 263-264): 
-Administrations tend to act rationally according to certain cost-benefit analysis.

-The primary purpose of a country's policy is to secure its own existence.

-Only states have the ability and legitimacy to act externally politically.

States can be considered identical in their characteristics, but of course, they differ on the basis of their military, economic and technical capabilities. Depending on the distribution of these capacities, they can have a say in the international system.

According to the neo-realist approach, the state can form alliances when necessary due to its interests. These alliances can also be between states located at opposite poles. Despite this alliance formation, it should not be assumed that a unique form of cooperation can develop between states. Such alliances are in most cases very short-term because changes in the power line-up can occur and are therefore very fragile. As a result, the prospect of comprehensive cooperation, even alliances and institutions among states, is of course extremely difficult. These will only happen if there is a concrete threat to the survival of a state (Düzgün, 2020:269-271).

Considering the Eastern Mediterranean problem in this context, both the agreement between Turkey and Libya and the agreement between France, Greece, Southern Cyprus, Egypt, and Libya are an alliance of interests and can only be valid as long as this interest continues. According to neorealism, the international system has an anarchic structure, and every state tries to maintain the balance of interests and power to guarantee its security within this system (Kökyay, 2020: 2508).

\section{THE PLACE OF NEO-LIBERALISM THEORY IN INTERNATIONAL RELATIONS AND THE EASTERN MEDITERRANEAN PROBLEM}

Neo-liberalism basically stands out as the most realistic and updated approach to capitalism or the capitalist market economy. Neo-liberalism has little to do with political liberalism, and in a decisive respect, they can even be seen as antagonists. Political liberalism represents the primacy of political freedoms and fundamental rights over pure economic freedoms. Neo-liberalism reverses this relationship. According to neo-liberalism, 
economic freedoms come first. In other words, if the economy is good, everyone is good, the approach is dominant (Safi, 2018: 1786-1789).

While the state establishes and regulates the market in political liberalism, the market is expected to regulate and shape the whole society in neoliberalism. The principles of neo-liberalism are not freedom, equality and fraternity, but freedom of competition and property. In this respect, even democratic countries may find it appropriate to support the party that brings them more economic benefits, rather than the principles of freedom and equality, when their economic interests are in question (Yan1k, 2015:4750). Due to the geopolitical location of the Eastern Mediterranean and its rich fossil energy resources, the world market is especially aimed at Western countries, and it is tried to benefit from these resources by creating energy pipelines (Ediger, Devlen, Mcdonald, 2012:78). As a matter of fact, France, which follows a predominantly neo-liberal policy, supports the Greek side in the Eastern Mediterranean issue, both for political and economic reasons (Yanık, 2015: 45).

\section{THE PLACE OF ENERGY RESOURCES IN INTERNATIONAL RELATIONS}

Energy sources are different energy carriers which can be suitable for industrial use and home use, for example, Hard coal, natural gas, crude oil, hydropower, etc. The current economic situation and the increasing global demand for crude oil and natural gas support situations where these energy resources can be used by suppliers as a means of pushing political interests. The oil crisis of the 1960s can be seen as a precedent in this context. Energy resource producers of states are sometimes faced with the accusation that they instrumentalize their energy resources for political purposes (Şengöz, 2019:10-14).

After the First and Second World Wars, especially because of industrialization, the energy consumption of countries increased. This increasing energy consumption cannot be prevented as technological development and people's needs do not decrease. Fossil fuels account for the largest portion of total energy consumption and these fuels are becoming increasingly scarce. On the other hand, there is a great need for fossil energy, but not every country has sufficient oil and natural gas resources. Therefore, every country is in search of claiming rights on the 
areas where this resource exists or obtaining a right by intervening in the problems of that region and country (Baysal, 2012:220-223).

In the 21 st century, when neo-liberalism is dominant, the concepts of energy dependence, energy supply security and energy demand play a major role in international relations. In international relations, the economic growth of states depends on energy and energy is the main source of people's daily lives. For this reason, energy should be transported and guaranteed through uninterrupted and secure supply relations between countries. Due to the needs of globalization, the energy demand of large, industrialized countries and especially developing countries such as Turkey is getting more and more attention around the world. Therefore, energy supply plays a big and important role in both political relations and economic cooperation. Energy is an important indicator for countries to make their economic growth sustainable. For this reason, states want to meet their energy needs at cheap prices, with safe transportation routes, with less dependency and uninterruptedly (Furuncu, Akbaş, 2019:1725).

In this context, oil and natural gas are the most important energy sources. Countries are accelerating their research and exploration activities for environmentally friendly and inexpensive new energy sources such as natural gas. In this respect, the areas where new natural gas, oil, gold, and other underground reserves can be found are the new focus of the powers that are in search of resources. On the other hand, major international powers are using their power against each other to benefit more from these regions in terms of economic policy. In this respect, the estimated natural gas reserves in the Eastern Mediterranean are of great interest. More importantly, the limited energy resources and especially the regions and countries where there are reserves such as natural gas come to the fore. Moreover, countries are highly dependent on other countries with these reserves in terms of their energy needs. In this context, there is a mutual dependency between countries. In other words, there is a mutual dependency between countries in terms of energy production, supply, consumption, and energy transportation (Çukurçayır, Sağır, 2008:258260).

As we mentioned above, Europe's energy demand is always increasing and at the same time, European energy resources are decreasing. Oil and 
gas are the keys to economic political power, anyone who owns them can own and dominate the world, then exercise their political and economic will. The European Union imports about $26 \%$ of its natural gas needs from Russia. In this respect, it can be considered as a correct policy according to both neo-liberal and neo-realistic approaches that the EU should take sides with Cyprus and Greece, which are its members, in the discussions about its reserves in the Mediterranean, to reduce its energy dependence even partially (Güneş, Arslan, 2018: 39-40).

This fact can also be explained within the framework of the theory of interdependence. According to this theory, it assumes that the saving power on resources determines the assertiveness of the actor. States and their existence are accompanied by political power plays and power processes. Their interrelationship is an area of analysis in the interdependence approach. This approach focuses on domestic and foreign policy events. According to the theory of interdependence, a single state today is unlikely to make decisions without dialogue with other states that will lead to changes across national borders. This is, of course, a result of the ever-evolving globalization. In this context, energy projects create mutual dependence (Kakışım, 2019:70). Ultimately, when Turkey wants to increase its energy resources and become at least self-sufficient and even an energy exporting country, it is involved in an intensive study on the Eastern Mediterranean natural gas reserves (Öztopal, Yiğittepe, 2020:262-265).

\section{WHY DO NATURAL GAS RESERVES ESTIMATED IN THE EASTERN MEDITERRANEAN REGION CAUSE PROBLEMS BETWEEN TURKEY AND GREECE?}

There are several reasons for the conflict between Turkey and Greece in the Eastern Mediterranean. These:

- Continental shelf uncertainty

-Economic value of natural gas reserves estimated to be in the region

•Turkey’s "Blue Homeland” policy

-The presence of other powers, especially France, as a balancing factor in this region 
Both states have been in conflict for years over sovereign territories in the Aegean Sea and the future of the divided island of Cyprus. When the discovered energy reserves are added to these problems, when it gains a new dimension as the "Eastern Mediterranean Problem", Greece focuses on creating strategic economic and political alliances and aims to conclude the conflict with Turkey in its favor (Ayaz Avan, 2020:99-102).

\section{RELATIONS BETWEEN TURKEY AND GREECE FROM NEO-LIBERAL AND NEO-REALIST PERSPECTIVES}

While the relations between Turkey and Greece follow a neo-liberal course, they display a neo-realist approach in problematic areas. That is, while Greece is a member of NATO and the EU, Turkey, as a country that is undergoing the EU membership process and is a member of NATO and the customs union, acts together in common areas in the same international arena as well as neighborly relations with Greece. The fact that supranational structures such as NATO and the EU take sides in the Eastern Mediterranean problem or assume the role of balancing mediator can be explained by neo-liberalism. Because, according to this theory, nonstate actors play a role in the international arena, and these supranational structures are effective in ensuring security for the smooth functioning of the free market and the protection of interests. Thus, the circulation of international economic activity will be ensured to function without interruption (Minister, Şahin, 2018:143-144).

In this respect, the two countries cooperate within the framework of neoliberal economic policies, especially in economic matters. For example, there are no restrictions on tourism activities between the two countries, and Turkish tourists can visit the Aegean Islands without a visa. From this point of view, despite the political disagreements, it is seen that there is a cooperation between them due to economic interests. This is in line with the neo-liberal spirit. Because according to neo-liberalism, economic interest is considered above all problems. On the other hand, the ambiguous issues such as the Cyprus problem, continental shelf problems, the Kardak Islands, and finally the Eastern Mediterranean natural gas reserves seem closer to the neo-realist theory approach. By establishing alliances in the two countries, each tries to shape the balance of power in their favor (Örmeci, 2021:101). 


\section{THE EASTERN MEDITERRANEAN PROBLEM IN TERMS OF INTERNATIONAL LAW REGULATION}

The coastal rights of countries are regulated by the 1982 United Nations Convention on the Law of the Sea. This provides an "Exclusive Economic Zone" (EEZ) to which a coastal state is the sole owner, and each country uses the mineral resources in this zone. This EEZ extends from the coastline to the border of 200 nautical miles, which is equivalent to about 370 kilometers. If the coast of another country is closer, the arithmetic center is the border. However, Turkey is not a party country since it has not signed the UN Convention on the Law of the Sea (Alper, 2020:30-35). On the other hand, the attitude of the EU, led by France, in this issue is based on international practices and presents a situation against Turkey. According to this view, which is the basis of the EU's position, at least some parts of the UN Convention on the Law of the Sea gain legal value due to international practices and therefore also apply to non-contracting states. In this respect, it is argued that this contract is binding within Turkey (Ayaz Avan, 2020: 93).

Turkey, on the other hand, argues that the continental shelf of its country, that is, the sea floor that extends to the Turkish coast, is the determining factor. Therefore, this situation gives Turkey an EEZ and the right to use the mineral resources around the Greek islands. In particular, Ankara denies that an island like Cyprus has its own continental shelf and can therefore claim its own economic zone (Erçakıca, 2021:266). The sharing of maritime areas negotiated between Turkey and Libya is based on this reasoning. However, this view is debated in international law and leads to objections. Especially those who oppose Turkey's thesis accuse the Turkish government of being inconsistent here. According to these, although Turkey does not recognize the continental shelf of an island state like Cyprus, it has determined the maritime borders with the north of Cyprus (Ünver Noi, 2019:14-15).

\section{WHY IS FRANCE INTERVENING IN THE EASTERN MEDITERRANEAN PROBLEM?}

France articulates its views on preventing these searches with the allegation that Turkey's natural gas exploration activities are against the Law of the Sea. Paris has openly sided with Greece, which sees Turkish activities as 
illegal. Mutual military harassment in June revealed how tense relations between the two countries were. In order to have a greater say in the Eastern Mediterranean problem, France is trying to pursue a policy by considering its political and economic interests. In this respect, the Right Mediterranean conflict between Turkey and France is above all the result of various strategic conflicts of interest between the two countries. For this reason, Turkey's expansionist policy extending to Libya on this region is met with a special resistance in France, which sees itself as the regulatory power of the Mediterranean region (Örmeci, 2021:99-105).

From both a neo-liberal and a neo-realist perspective, Greece is in a weaker position vis-à-vis Turkey both economically and politically. In this respect, Greece resorts to the balancing strategy. According to the neo-realism balancing strategy, the side that is in a weaker position compared to its opponent seeks a stronger ally in order to be better equipped against the opponent. Thus, by getting his help, he strengthens his position. According to this majority strategy, a weak country usually engages with a potential enemy of its rival, thereby preventing any possible danger to its nation (Waltz, 1979:126). Strategies have pros and cons. However, this strategy is one of the foremost balancing/defensive approaches of neo-realist theory. Here, France represents a balancing partner against Turkey for Greece in the Eastern Mediterranean issue (Tuna, 2020:82-85).

Greece follows an international balancing policy based on the assumption that Turkey will try to weaken its position in the Eastern Mediterranean and that France will strengthen Greece's position. France, on the other hand, as a strong member of the European Union and a country with a coast in the Mediterranean, sees it as suitable for its own economic and political interests to stand by Greece, which is an EU member like itself. If we look at it with a neo-liberal approach, France's economic interests brought a cooperation with Greece.

Natural gas exploration activities in the Eastern Mediterranean region of Turkey conflict both economically and politically, especially in terms of France's position in the European Union region. In particular, the uncertain legal status of the natural gas reserves region, which is estimated to be in the Eastern Mediterranean region, in terms of international law makes it easy for France to intervene in the issue. 
Especially under the leadership of Macron, the foreign policy of France sees Turkey as an important economic and political rival in the region. Likewise, under the leadership of Erdogan, Turkey's offensive neorealist or Ottomanist policy, which aims to discover new energy resources and become a stronger country in its region, plays an effective role in the confrontation between France and Turkey in the Eastern Mediterranean region. In other words, since the problem between Greece and Turkey touches the interests of France, France gets involved in the problem. If we look at this approach of France from the perspective of neo-realism, it is acceptable to act pragmatically in international relations, especially for security reasons, and to establish cooperation and new alliances for a short time accordingly (Şeker, 2019:285).

France not only stated that it sided with Greece, but also made diplomatic efforts to encourage stabilizing forces such as NATO and the USA to act in favor of Greece. France also aimed to limit Turkey's maneuvers in the region by making cooperation agreements with Egypt and Libya (Algür, 2020:58). As a result, Greece turned the balance of power in its favor, causing Turkey to suspend natural gas exploration activities in the region. As a matter of fact, ORUÇ REIS, which was carrying out natural gas exploration activities in the region, withdrew. However, this development does not mean that Turkey abandons its pursuit of rights in this region (Oral, 2021:227).

France aims to weaken Turkey's position in the Mediterranean region by cooperating not only with Greece and Southern Cyprus, but also with the countries in the region, especially Egypt and Israel. From this point of view, both Greece and France follow a neo-liberal policy economically, while politically emphasizing a neo-realist approach.

As it is known, neo-liberalism in international relations is a school of thought that believes that states are primarily concerned with absolute gains rather than relative gains compared to other states, or at least should be (Yan1k, 2015: 45). From this point of view, if Turkey discovers natural gas reserves in the Eastern Mediterranean, these reserves are relatively to the benefit of France. Because the natural gas to be extracted will be easily transported to Europe and its cost will be low, it will contribute to meeting the natural gas needs of Europe, even partially. However, since Turkey will 
get the lion's share of these possible reserves, this situation will be against France in terms of absolute gain.

As a result, both Turkey, Greece, Greek Cyprus, and France want to gain the status of great power internationally and regionally within the framework of their quest to have energy resources or to cooperate with countries that have these resources. Furthermore, according to Aybar, the problem of the Eastern Mediterranean above and beyond France, other Mediterranean region countries such as Egypt and Israel also want to be indirectly involved in order to defend their own interests, or they are making efforts in this regard (Aybar, 2018).

\section{CONCLUSION AND RECOMMENDATIONS}

The start of natural gas exploration activities in the Eastern Mediterranean with the Oruç Reis research ship to reduce Turkey's dependence on foreign energy and to explore potential energy sources has led to an international problem coming to the fore once again. As a matter of fact, this active policy faced obstacles not only by Greece but also by France and many other Mediterranean countries.

Thus, the problems between Greece and Turkey have reached the level of an international problem with the involvement of many countries since the discovery of natural gas energy reserves in the Eastern Mediterranean is a great economic power. While Turkey resolutely wanted to continue its work on gas reserves in the Eastern Mediterranean with the emphasis on the "Blue Homeland", EU member states such as Greece and France tried to prevent Turkey's efforts on an international basis.

It does not seem possible to solve the Eastern Mediterranean natural gas reserves problem and the conflicts arising from it soon. In addition to the dispute over the natural gas reserves in the Mediterranean, Greece's attitude towards Cyprus and its constant efforts to put Turkey under pressure, especially in the EU, render efforts to solve such problems inconclusively.

Greece and Turkey, the natural gas reserves in the Eastern Mediterranean are actually only part of the problems that have been going on for a century. It still has uncertainties since the Aegean islands were ceded to Greece after the Treaty of Lausanne. So far, both sides are discussing how the area between the Greek islands and the Turkish coast can be used, and the 
issue has not been resolved definitively. Therefore, international powers are involved in this process for economic and political reasons. It was tried to explain this in a more understandable way with neo-realist and neoliberalist approaches. On the other hand, this problem is a multifaceted and multi-actor problem as it used to be. Therefore, countries and powers such as France, the EU, the USA, Egypt, Israel, and Libya are also involved in the problem due to their own economic and political policies. In addition, Turkey's policy in the Eastern Mediterranean is considered as a requirement of its national interests. This approach can be explained by realism. Because, according to this theory, security and national interests come to the fore as the main factors that determine a country's foreign policy (Demirtaş, Bagdonas, 2012: 2).

Turkey's natural gas exploration efforts in the Eastern Mediterranean have not made any concrete progress so far due to the international initiatives of Greece supported by France. However, Turkey, both as a country with a coast on the Mediterranean and as a guarantor country of the Turkish Republic of Northern Cyprus, will not give up this right. In this respect, the conflicts with Greece, especially the Cyprus problem, will of course be reflected in all kinds of activities of Turkey in this region. However, Turkey's view on the solution of the issue through negotiations is important in finding a political solution to the problem. Because this problem has both an international dimension and an important energy source such as natural gas can cause conflicts of interest with other countries in the region. In this respect, the problem itself is complex and its solution requires an equally multidimensional approach. In this respect, in this study, we tried to evaluate the subject mainly from neo-liberal and neo-realist perspectives.

As a result, the evaluation of the problems that emerged within the framework of Turkey's latest Eastern Mediterranean natural gas exploration initiatives can be summarized with the following results:

-This problem is seen as a part of the Cyprus problem in terms of international politics.

-If the Cyprus problem is not resolved in terms of international law, such problems will arise from time to time in the Aegean and Mediterranean regions.

-This problem is not only seen as a problem between Turkey and Greece. 
-Economic and political interests in this region force other countries to be involved in the problem.

There are problems between Turkey and Greece regarding the status of the Aegean Islands, the Cyprus problem, and ultimately the natural gas reserves in the Eastern Mediterranean and gaining an international dimension. Especially the Eastern Mediterranean Problem increases the interest of many countries in the region, both politically and economically, due to the natural gas reserves that are estimated to be in the region. In this case, the more countries are involved in the problem, the more difficult the solution becomes, especially for Turkey. Because Turkey is already under pressure in the international arena because of the Cyprus problem. For example, the Cyprus problem is one of the biggest obstacles to Turkey's EU full membership process. In this respect, Turkey's approach to the Eastern Mediterranean and Blue Homeland policy is negative due to the EU countries' perspective on the Cyprus problem, especially France. In this respect, the solution of the Eastern Mediterranean problem largely depends on the solution of the Cyprus problem and the development of Turkey-EU relations. However, these problems cannot be solved in the short and medium term, both in terms of Turkey and Greece, within the framework of current policies.

Ultimately, the conclusion that the Eastern Mediterranean natural gas reserves issue is a difficult and unsolvable problem in the short term comes to the fore. Looking at the policy he followed for Turkey's security and economic interests from a neo-realist perspective, it was an indication that he followed a policy at an international level that would ensure the security of the nation-state structure, which includes military and economic factors. Turkey's attempts to protect its own interests in this issue will continue. Especially, Turkey's ability to operate in this region with its own technical facilities and research vessels provides a great advantage for Turkey. However, from a realistic point of view, it does not seem possible to conclude the problem in favor of Turkey in the short term, since underground resources such as natural gas and oil require international competition and a balance of power. In this respect, the issue of how the problem will evolve in the future will be an important topic of discussion for international relations and political science. 
Examining the Economic and Political Dimensions of the Eastern Mediterranean Problem from a Macroeconomic Perspective within the Framework of Neo-Realism and Neo-Liberalism

\section{REFERENCES}

[1] Aybar, A. (2018). 'Doğu Akdeniz Enerji 'Dalaşıı' ve Mısır- İsrail Yakınlaşması”, https://tasam.org/tr-TR/Icerik/50228/dogu_akdeniz_ enerji_dalasi_ve_misir_-_israil_yakinlasmasi /Erişim tarihi: 20.09.2021

[2] Alper, G. (2020). “Uluslararası Hukuk Çerçevesinde Doğu Akdeniz’deki Münhasır Ekonomik Bölge İlanları ve Sınırlandırmaları: Türkiye'nin Güvenliği ve KKTC Üzerindeki Etkiler", Anadolu Strateji Dergisi, 2 (2), 29-42.

[3] Algür, B. (2020). “Kıbrıs ve Doğu Akdeniz'deki Son Uluslararası Gelişmeler Işığında Değiş̧en Türkiye, ABD ve NATO Politikaları", Anadolu Strateji Dergisi, 2 (2), 55-70.

[4] Ayaz Avan, E. (2020). "Doğu Akdeniz Deniz Yetki Alanları Sorunu: Türkiye'nin Politikası ve AB'nin Yaklaşımı”, Avrasya Etüdleri, 58 (2), 87112.

[5] Baysal, K. (2012). “Íkinci Dünya Savaşı Sonrasında Petrol Analizi”, İstanbul Üniversitesi İktisat Fakültesi Mecmuas1, 35 (1-4).

[6] Bakan, S. \& Şahin, S. (2018). "Uluslararası Güvenlik Yaklaşımlarının Tarihsel Dönüşümü ve Yeni Tehditler", The Journal of International Lingual Social and Educational Sciences, 4(2), 135-152.

[7] Çukurçayır, M. \& Sağır, H. (2008). "Enerji Sorunu, Çevre ve Alternatif Enerji Kaynakları”, Selçuk Üniversitesi Sosyal Bilimler Enstitüsü Dergisi, (20), 257-278.

[8] Düzgün, D. (2020). "Realizm Teorisinin Ortaya Çıkışı ve Gelişme Evreleri”, Karadeniz Uluslararası Bilimsel Dergi, 1 (47), 256-276.

[9] Demirtaş Bagdonas, Ö. (2012). Post-Yapısalcılık ve Dış Politika: Türkiye'nin Kıbrıs Söyleminde «Milli Çıkar»ın İnşası, İçinde: Dış Politika Analizinde Teorik Yaklaşımlar: Türk Dış Politikası Örneği, Barış Yayınları, ss. $53-82$.

[10] Ediger, V. Ş., Devlen, B. \& McDonald, D. B. (2012). "Levant'ta büyük oyun: Doğu Akdeniz’in enerji jeopolitiği”, Uluslararası Illişkiler Dergisi, 9(33), 73-92. 
[11] Erçakıca, M. (2021). “Doğu Akdeniz'de Yaşanan Güncel Gelişmelerin Kıbrıs Sorunu ve Uluslararası Deniz Hukuku Çerçevesinde Değerlendirilmesi”, Erciyes Üniversitesi Hukuk Fakültesi Dergisi, 16 (1), 301-334.

[12] Furuncu, Y. \& Akbaş, Z. (2019). "Neoliberal Teori Ekseninde Küreselleşmenin Türkiye'nin Enerji Politikaları Üzerindeki Etkileri: Enerji Ticareti Boyutu", Elektronik Sosyal Bilimler Dergisi, 18 (72) , 1724-1741.

[13] Güneş, M. \& Arslan, T. (2018). "Enerji Bağımlılığında Avrupa Birliği, Rusya, Türkiye Üçgeni ve Doğu Akdeniz Alanı”, International Journal of Humanitiesand Education.

[14] Oral, F. (2021). "Is the Crisis in the Eastern Mediterranean: Is it About Energyor Sovereignty?", Uluslararası Kriz ve Siyaset Araştırmaları Dergisi, 5 (1) , 219-247.

[15] Örmeci, O. (2021). “Fransa'nın Doğu Akdeniz Politikasını ve Türkiye ile Yaşanan Güncel Gerginlikleri Anlamak", UPA Strategic Affairs 2 (2021): 96-118.

[16] Öztopal, M. \& Yiğittepe, L. (2020). “Türkiye’nin Enerji Güvenliği Bağlamında Doğu Akdeniz'de Enerji Rekabeti”, Akademik Bakış Uluslararası Hakemli Sosyal Bilimler Dergisi, 259-272.

[17] İlhan, S. (2019). "Neo-Liberalizm, Esneklik ve Güvensizlik", Firat Üniversitesi Sosyal Bilimler Dergisi, 29 (2), 361-368.

[18] Kakışım, C. (2019). "Karşılıklı Bağımlılık Kapsamında TürkiyeRusya Enerji İlişkilerinin Analizi”, Uluslararası Siyaset Bilimi ve Kentsel Araştırmalar Dergisi, Cilt 7, Say1 1, ISSN 2630-6263, ss. 67-89.

[19] Kökyay, F. (2020). “Neorealizm Kuramı ve Türkiye’nin Doğu Akdeniz Enerji Politikası”, İnsan ve Toplum Bilimleri Araştırmaları Dergisi, 9 (3), 2504-2528.

[20] Ünver Noi, A. (2019). "Doğu Akdeniz'de ABD, AB ve Türkiye İlişkileri Nereye?” EURO Politika, 3 (2), 13-16.

[21] Ünay, S. (1998). "Yapısal realizm ve ötesi Kenneth Waltz'un 'Uluslararası Siyaset Teorisi'ne eleştirel bir yaklaşım”, Divan: Disiplinlerarası Çalışmalar Dergisi (1998): 207-216. 
[22] Safi, İ. (2018). "Neo-Liberalizmin Öncüsü Hayek'in Toplumsal ve Siyasal Kuramı", OPUS Uluslararası Toplum Araştırmaları Dergisi, 9 (16), 1770-1793.

[23] Şengöz, M. (2019). “Ekonomik Savaş Enstrümanı Olarak Global Enerji Politikaları Üzerine Bir Kritik, Enerji Güvenliği Yönetimi”, Journal of Social SciencesandHumanities, 3 (2) , 0-0.

[24] Şeker, B. Ş. (2019). Doğu Akdeniz Enerji Güvenliği Ekseni: Yunanistan-Gkry'nin Muhtemel Politikalarının Analizi ve Türkiye'nin Tutumu, Tasam Yayınlar1, ISBN:978-605-4881-35-2, ss.280-319.

[25] Tuna, F. (2020). “Türk Dış Politikasında Realist Yaklaşım: Türkiye’nin Doğu Akdeniz ve Libya Politikası", Uluslararası Hukuk ve Sosyal Bilim Araştırmaları Dergisi, 2 (1), 74-87.

[26] Yayc1, C. (2012). "Doğu Akdeniz'de Deniz Yetki Alanlarının Paylaşılması Sorunu ve Türkiye, Bilge Strateji, Jeopolitik", EkonomiPolitik ve Sosyo-Kültürel Araştırmalar Dergisi, Cilt 4, Sayı 6, Bahar 2012, ss. 1-70.

[27] Yanık, L. (2015). "Liberalizm: Bir Yazın Değerlendirmesi", Uluslararası İlişkiler Dergisi, Özel Sayı: Uluslararası İlişkilerde Kuramsal Okumalar, 34-55.

[28] Yirmibeşoğlu, Ş, \& Yaşar Dinçer, F. (2018). "Uluslararası Ticaret Bağlamında Klasik Realizm, Neo-Realizm ve Neo-Liberalizm”. Akdeniz Üniversitesi Sosyal Bilimler Enstitüsü Dergisi, (3), 114-127.

[29] Waltz, K. N. (1979). "Theory of International Politics. Massachusetts: AddisonWesley Publishing Company" 